\title{
Differences in the Environmental, Social and Economic Development of Polish-Lithuanian Trans-Border Regions
}

\author{
Katarzyna Pawlewicz ${ }^{1}$ (D) Adam Senetra ${ }^{1}$ (D) Marta Gwiaździńska-Goraj ${ }^{1}$ (D) . \\ Dovilè Krupickaité ${ }^{2}$
}

Accepted: 14 August 2019 / Published online: 24 August 2019

(C) The Author(s) 2019

\begin{abstract}
Regional development is a complex process that can be analysed in various contexts, including environmental, social and economic factors. Variations in the levels of development are naturally observed across countries and regions, but they play a special role in trans-border regions. The aim of this study is to investigate differences in the level of development of two Polish voivodships (Warmia and Mazury, and Podlasie) and two Lithuanian counties (Marijampole and Alytus) which are trans-border regions (NUTS 4 level). The study was conducted by analysing three subordinate criteria, namely environmental, social and economic factors, as well as the overall development of the evaluated regions with the use of the analytical hierarchy process and technique for order preference by similarity to ideal solution methods. The evaluated trans-border regions are characterised by a predominance of rural areas and considerable variations in development. The entire area is characterised by high natural value. This is an important observation because the condition of the natural environment is a key determinant of well-being, and it directly influences the quality of life. The analysis revealed considerable demographic problems, mainly in Lithuanian regions, resulting from low population growth and a negative net migration rate which influence population structure. Disproportions in regional development call for regional policies that are adapted to local needs and resources.
\end{abstract}

Keywords Regional development · Trans-border regions · Polish and Lithuanian regions · TOPSIS $\cdot$ AHP $\cdot$ Synthetic indicator

\section{Introduction}

Development is a highly complex and multi-faceted process. It can be defined as any longterm process of directional changes which is composed of successive stages of transformation and produces discernible differences in an object in the evaluated context (Nowa encyklopedia powszechna 1996). Development is driven by the motivation to achieve an ideal (model) state where the differences between territorial units are levelled out.

Adam Senetra

adam.senetra@uwm.edu.pl

Extended author information available on the last page of the article 
Development induces positive changes that drive quantitative growth and qualitative progress in economic, social and environmental systems (Markowski 2008; Kowalik et al. 2017). These transformations are closely related to the concept of sustainable development which aims to achieve higher levels of economic and social growth while improving or at last not deteriorating the condition of the natural environment (Borys 2005; Markowski 2008).

Regional development is largely determined by the availability of local resources. The resource base of a territorial unit influences its level and directions of development, and it contributes to an improvement in the quality of life. Resources can be divided into two main categories: man-made and natural assets (Pawlewicz et al. 2015). It should be noted that every territorial unit is characterised by variations in natural and man-made resources. Therefore, in order to equalize the level of development, one should try to diversify economic structures that take into account the potential of these resources. The environmental, social and economic factors that drive regional development have to be identified. The influence of the constituent elements of every factor and their significance in the development process are generally determined by the unique potential of the analysed region.

Variations in regional development are encountered in every country and every region of the world, and they have been long studied by economists, ecologists, sociologists and geographers. Local potential should be maximally harnessed to protect regions against marginalisation and peripheralisation, to improve local standards of living and contribute to the development of the global economy.

Variations in development are a particularly important criterion in analyses of transborder regions. These areas are located peripherally and far from economic hubs, which can further deepen the observed divide (Gwiazdzinska-Goraj and Jezierska-Thole 2013; Mitriča et al. 2017). Research into trans-border areas often focuses on the quality of life to propose strategies for improvement in areas with the lower levels of social and economic development (Martin 2001; Pacione 2003; Angelovič and Ištok 2016). For many years, social policy has been one of the most important and effective tools for stimulating regional growth (Veenhoven 2002). The development of trans-border regions also has important implications for a country's territorial security (Newman and Paasi 1998; Song et al. 2017) and the condition of the natural environment (Senetra et al. 2013).

The aim of this study was to analyse variations of the development of Polish-Lithuanian trans-border regions. The study was conducted by analysing three subordinate criteria, namely environmental, social and economic factors, as well as the overall development of the evaluated regions at the NUTS 4 level (as at 1 January 2017).

\section{Materials and Methods}

\subsection{Study Area}

Four administrative units were analysed in the study: the Warmia and Mazury voivodship and the Podlasie voivodship in Poland, and the Lithuanian counties of Marijampole and Alytus (Fig. 1). The evaluated trans-border regions occupy a total area of $54,243 \mathrm{~km}^{2}$ and have a combined population of more than 2.9 million. All units are NUTS 4 statistical regions. Research into trans-border regions at the NUTS 4 level has been conducted by Senetra et al. (2013), Churski et al. (2014) and Krupickaite et al. (2014). The development of the analysed regions has been influenced by similar factors, including their peripheral 

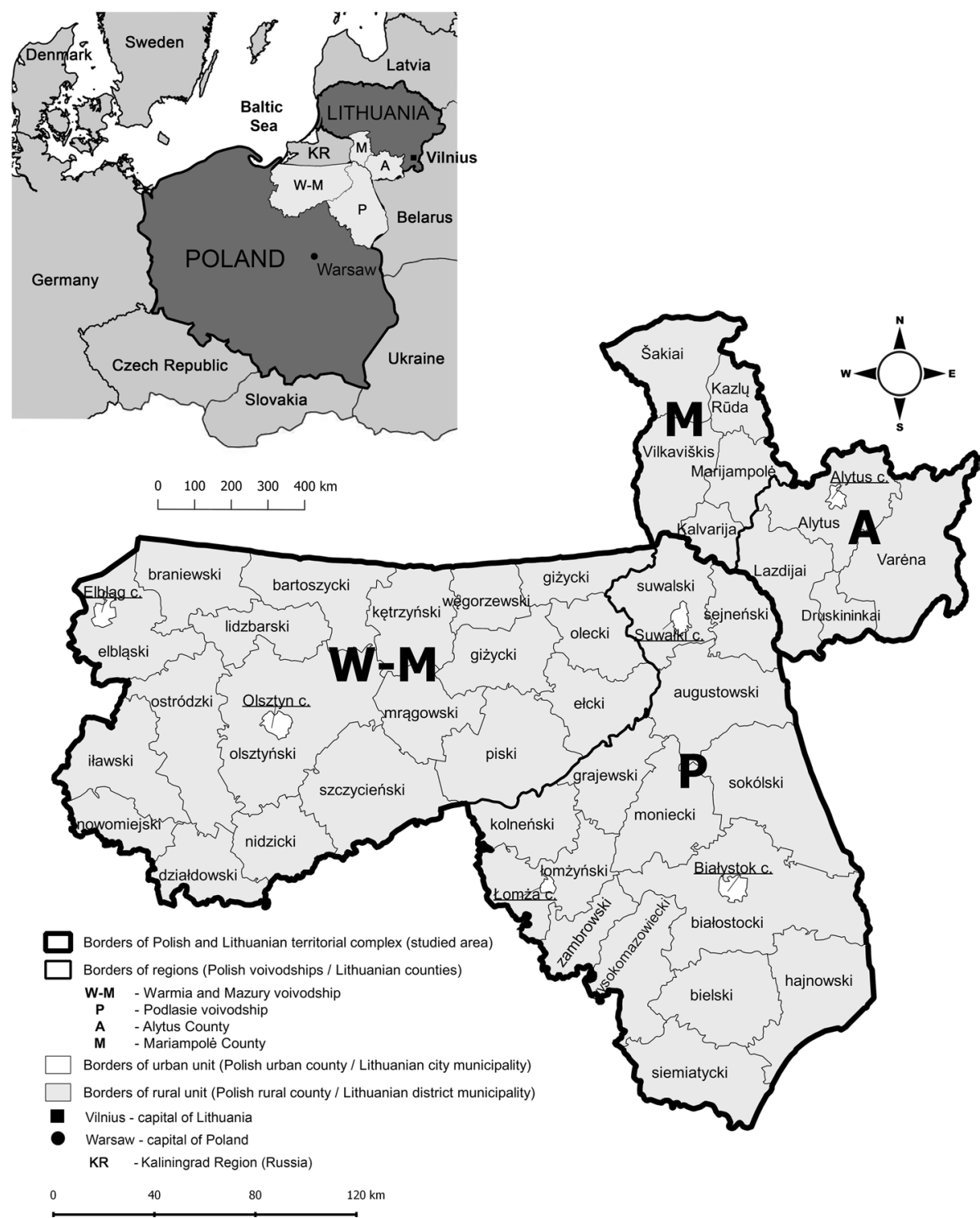
Agricultural land occupies more than 50\% of the region's territory, and the local economy is based heavily on agriculture (Wyniki narodowego spisu 2012). Warmia and Mazury has an area of $24,173 \mathrm{~km}^{2}$, and it is inhabited by around $4 \%$ of the Polish population. Podlasie has an area of $20,187 \mathrm{~km}^{2}$, and it is inhabited by around $3 \%$ of the Polish population. At the end of 2016, population density was estimated at 59 persons per $\mathrm{km}^{2}$ in both voivodships (the Polish average is 123 persons) (www.stat.gov.pl, accessed on 2.07.2018). The key priorities in the development strategies of the analysed regions include the promotion of tourism based on natural resources and cultural heritage, harnessing the opportunities that arise from the trans-border location of the regions, increasing their attractiveness for investors, environmental protection and the development of transport networks (Senetra et al. 2013).

The Lithuanian counties of Marijampolè and Alytus have unique features, and they differ from each other and from Lithuania as a whole. Marijampole is characterised by a predominance of productive clayey flat land or rolling clayey lowland. Hills and lakes are encountered only in the southern part of the county. Marijampole has one of the lowest percentages of forest cover in Lithuania. The agricultural sector in Marijampole has been visibly revived after Lithuania had regained its independence. Alytus county is characterised by the highest degree of naturalness relative to other parts of Lithuania, and it features mostly unproductive sandy plains, lakes, hills and pine forests (Mačiulytė et al. 2012; Senetra et al. 2013). Alytus has an area of $5418 \mathrm{~km}^{2}$, it is inhabited by around $8 \%$ of the Lithuanian population, and its population density is estimated at 26 persons per $\mathrm{km}^{2}$ (as at January 2017). Marijampole has an area of $4465 \mathrm{~km}^{2}$, it is inhabited by around $7 \%$ of the Lithuanian population, and its population density is estimated at 33 persons per $\mathrm{km}^{2}$ (the Lithuanian average is 44 persons) (www.osp.stat.gov.lt accessed on 28.05.2018).

The analysed regions are bound by a cooperation agreement which was signed on 6 June 1997 in Augustów, Poland, by the authorities of trans-border regions in Poland, Lithuania and Belarus (and later Russia). This event gave rise to the Niemen Euroregion Association which covers the Podlasie voivodship, a large part of the Warmia and Mazury voivodship, and the Lithuanian counties of Alytus and Marijampole, i.e. nearly the entire analysed territory which is regarded as a cohesive Euroregion. In 2007-2013, the Euroregion Niemen was covered by the INTERREG programme as part of the European Territorial Cooperation Objective financed by the European Regional Development Fund. Collaboration between the evaluated Polish and Lithuanian regions was established under a Cross-Border Cooperation Operational Programme (CBC OP) (Cross Border Cooperation Programme Lithuania-Poland 2007). The above indicates that the evaluated trans-border areas share many similarities and can be analysed as a cohesive region.

The territorial reach of the investigated areas in Poland and Lithuania is presented in Table 1.

\subsection{Methods}

Regional development is a multi-faceted process that cannot be measured and described with a single parameter. Complex phenomena are analysed with the use of synthetic variables where numerous indicators are expressed by a single synthetic variable (Milenkovic et al. 2014; Holgado Molina et al. 2015; Pérez et al. 2015; Ding et al. 2016; Fura and Wang 2017).

The search for metrics that facilitate assessments of regional development indicates that official statistics, although not free of defects, are the most reliable source of data. Various indicators are suitable for different types of analyses (Raupeliene et al. 2014). Parameters 
Table 1 Definition of territorial units

\begin{tabular}{ll}
\hline Unit & Territorial reach \\
\hline Studied area & Polish voivodships and Lithuanian counties-pooled data \\
Region & Poland-voivodships (Warmia and Mazury, Podlasie) \\
& Lithuania-counties (Alytus, Marijampolè) \\
Urban unit & Poland-urban county at the NUTS 4 level (5 urban units) \\
& Lithuania-city municipality at the NUTS 4 level (1 city municipality) \\
Rural unit & Poland-rural county at the NUTS 4 level (33 rural units including 84 \\
& towns) \\
& Lithuania-municipality and district municipality at the NUTS 4 level \\
& (5 municipalities and 4 district municipalities including 15 towns) \\
\hline
\end{tabular}

Source: Own elaboration based on the administrative division and statistical classification of Poland and Lithuania

that support comparisons of territorial units are most suitable for monitoring local changes. They are composed of input values, and any changes in the observed phenomena can be monitored in reference to those baseline values (Brodziński 2011) to generate information about social, economic and environmental processes in the evaluated territory.

The development of trans-border regions was evaluated with the use of the Technique for Order Preference by Similarity to an Ideal Solution (TOPSIS) method. In this reference method, Euclidean distances between each object (NUTS 4 unit) and positive and negative ideal solutions are calculated. The evaluated objects are ranked based on a synthetic indicator. The most highly developed objects are characterised by the shortest distance from the positive ideal solution and the longest distance from the negative ideal solution (Hwang and Yoon 1981; Wysocki 2010; Huang et al. 2011; Tzneng and Huang 2011). A synthetic indicator was developed for subordinate criteria (environmental, social and economic factors) and the main criterion (overall development of trans-border regions) with the use of the TOPSIS method according to the following procedure (Hwang and Yoon 1981; Wysocki 2010; Huang et al. 2011; Tzneng and Huang 2011; Łuczak and Wysocki 2012; Kusumawardani and Agintiara 2015; Hanine et al. 2016; Sarul and Eren 2016):

Stage 1. The available literature was analysed to select parameters (environmental, social and economic) describing the development of NUTS 4 units.

Stage 2. A system of weights was developed. In the TOPSIS method, a synthetic indicator is developed by assigning weights to simple parameters (indicators). The weights were determined based on expert opinions. The weights for subordinate criteria were developed first in the analytical hierarchy process (AHP) (Saaty 2000).

In the AHP method, a hierarchical diagram is developed by breaking down the analysed problem into constituent parts, i.e. the main criterion (overall development of trans-border regions) and the subordinate criteria (environmental, social and economic factors) and simple parameters (indicators) (Fig. 2).

Parameters (indicators) describing regional development were selected based on a review of the literature (Žičkienè 2004; Borys 2005; Vitunskiene et al. 2007; Heffner and Stanny 2007; Kompa 2009; Brodziński 2011; Bogdański 2012; Churski et al. 2014; Pociute 2014; Krupickaite et al. 2014; Streimikiene 2014; Rupliené et al. 2017). Indicators were selected for every subordinate criterion, and a total of 16 indicators were included in the analysis. Environmental factors as the subordinate criterion were described based on an analysis of natural resources, the quality of the natural environment and the utilization 


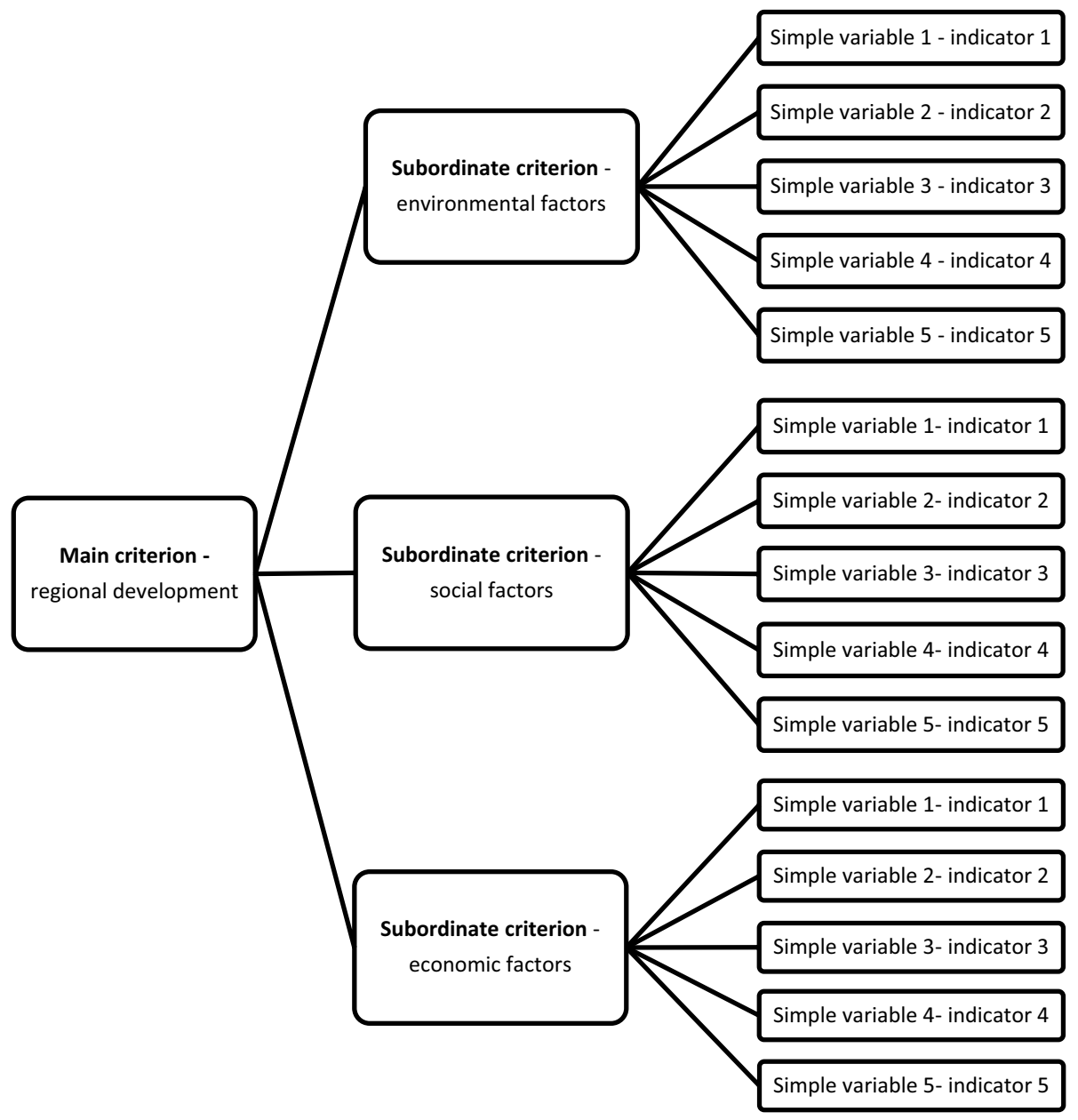

Fig. 2 Hierarchical structure of the analysed problem Source: Own elaboration

of environmental resources for human needs. Social factors as the subordinate criterion involved population growth, health and the standard of living. Economic factors as the subordinate criterion were related to the financial status of the analysed territorial units, local business activity and entrepreneurship. Variables were selected based on their availability and comparability between the two countries. The obtained data were valid for 2016 (data relating to the percentage of agricultural land in total land area were valid for 2013 because more recent statistical data were not available).

The weighting process begins with a pairwise comparison of subordinate criteria according to Saaty's 9-point scale (Table 2). The score is presented in an $n \times n$ matrix (1). The pairwise comparison matrix is composed of $n$ ones on the main diagonal. The comparison is performed by an expert who determines the influence of the elements on the left side of the matrix on the elements at the top of the matrix. The inverse of the pairwise comparison matrix is located below the main diagonal (Saaty 2000; Bryndza 2006; Łuczak and Wysocki 2012; Stoltmann 2015; Kluczek and Gładysz 2015; Mukherjee 2017): 
Table 2 Saaty's 9-point preference scale between two compared elements

\begin{tabular}{|c|c|c|}
\hline Importance & Weight & Definition \\
\hline \multirow{4}{*}{$\begin{array}{l}\text { The criterion is "more } \\
\text { important" for evaluat- } \\
\text { ing regional develop- } \\
\text { ment }\end{array}$} & 3 & Slightly more important \\
\hline & 5 & More important \\
\hline & 7 & Strongly more important \\
\hline & 9 & Absolutely more important \\
\hline Equally important & 1 & $\begin{array}{l}\text { Both criteria are equally important for evaluating regional } \\
\text { development }\end{array}$ \\
\hline \multirow{4}{*}{$\begin{array}{l}\text { The criterion is "less } \\
\text { important" for evaluat- } \\
\text { ing regional develop- } \\
\text { ment }\end{array}$} & $1 / 9$ & Absolutely more important \\
\hline & $1 / 7$ & Strongly more important \\
\hline & $1 / 5$ & More important \\
\hline & $1 / 3$ & Slightly more important \\
\hline Compromise alternative & $\begin{array}{l}2,4,6,8 \\
1 / 2,1 / 4,1 / 6,1 / 8\end{array}$ & $\begin{array}{l}\text { Intermediate values between two neighbouring scores can } \\
\text { be used if compromise alternatives have to be numeri- } \\
\text { cally interpolated }\end{array}$ \\
\hline
\end{tabular}

Source: Own elaboration based on Saaty (2000) and Stoltmann (2015)

$$
A=\left[\begin{array}{cccc}
1 & a_{12} & \ldots & a_{1 n} \\
\frac{1}{a_{12}} & 1 & \ldots & a_{2 n} \\
\vdots & \vdots & \vdots & \vdots \\
\frac{1}{a_{1 n}} & \frac{1}{a_{2 n}} & \ldots & 1
\end{array}\right]
$$

In the inverse pairwise comparison matrix, the $i$ th row is the reverse of the $i$ th column; therefore:

$$
A w=n w
$$

where $w$-column vector with elements $\mathrm{w}_{1}, \mathrm{w}_{2}, \ldots, \mathrm{w}_{\mathrm{n}}$.

The elements of eigenvector $w$ constitute a priority vector in view of the main objective of the analysis. The priority vector is derived with the following formula:

$$
w=\sum_{j=1}^{n} w_{j} * a_{i j}
$$

In the AHP approach, the highest eigenvalue of the matrix is also calculated to determine the consistency of comparisons relating to preference proportions. The matrix eigenvalue is calculated with the following formula:

$$
\lambda_{\text {max }}=\frac{1}{w_{i}} \sum_{j=1}^{n} a_{i j} * w_{j}
$$

A pairwise comparison is consistent if $\lambda_{\max }$ approximates $n$ (Stoltmann 2015 citing Babic and Plazibat 1998).

The consistency index (CI) is also calculated in the AHP method to determine deviations of the pairwise comparison matrix. The $\mathrm{CI}$ is calculated as follows:

$$
C I=\frac{\lambda_{\max }-n}{n-1}
$$


The consistency ratio (CR) is computed to determine the degree of inconsistency in comparisons of relative importance. The $\mathrm{CR}$ is computed from the following formula:

$$
C R=\frac{C I}{R I}, \text { where } C R \leq 0.1
$$

where RI is the random index which is calculated based on the below formula (Mukherjee 2017):

$$
R I=\frac{1.98 *(n-2)}{n}
$$

The above procedure was applied to every expert opinion. Expert opinions where $C R \leq 0.1$ were included in analysis. The weights for the analysed criteria were determined with the expanded AHP method proposed by Bryndza (2006) and Kluczek and Gładysz (2015). The weighting procedure is presented in Table 3.

In the next step, the weights for simple parameters (indicators) $\mathrm{w}_{\mathrm{j}}^{*}$ were calculated in each subordinate criterion. It was assumed that parameter (indicator) weights are identical in each criterion, and they were calculated by dividing the weight of a subordinate criterion $\left(u_{j}\right)$ by the number of simple parameters in the criterion $\left(\mathrm{n}_{\mathrm{p}}\right)$ (Wysocki 2010):

$$
w_{j}^{*}=\frac{u_{j}}{n_{p}} \text {, where } n_{p} \text {-number of simple parameters in the criterion. }
$$

The eigenvector was calculated based on the following formula:

$$
\mathrm{W}^{*}=\left[w_{1}^{*}, w_{2}^{*}, \ldots, w_{n}^{*}\right], \text { where } \sum_{j=1}^{n} w_{j}^{*}=1
$$

Stage 3. Indicator values were normalized with the following formula:

$$
r_{i j}=\frac{x_{i j}}{\sqrt{\sum_{i=1}^{m} x_{i j}^{2}}} \text { for } \mathrm{i}=1,2, \ldots, \mathrm{m} \text { and } \mathrm{j}=1,2, \ldots \mathrm{n}
$$

Stage 4. Normalized indicator values were weighted with the following formula:

$$
\mathrm{v}_{\mathrm{ij}}=\mathrm{r}_{\mathrm{ij}} * \mathrm{w}_{\mathrm{j}}^{*} \text { for } \mathrm{i}=1,2, \ldots, \mathrm{m} \text { and } \mathrm{j}=1,2, \ldots, \mathrm{n}
$$

Stage 5. The coordinates of ideal units-positive ideal solution $\left(\mathrm{A}^{+}\right)$and negative ideal solution $\left(\mathrm{A}^{-}\right)$- were determined based on the below formulas:

$$
A^{+}=\left(v_{1}^{+}, v_{2}^{+}, \ldots, v_{n}^{+}\right)
$$

where $v_{j}^{+}=\max v_{i j}$, when $\mathrm{j} \in \mathrm{S}$ and $v_{j}^{+}=\min v_{i j}$, when $\mathrm{j} \in \mathrm{D}$ for $\mathrm{j}=1,2, \ldots, \mathrm{n}$

$$
A^{-}=\left(v_{1}^{-}, v_{2}^{-}, \ldots, v_{n}^{-}\right)
$$

where $v_{j}^{-}=\min v_{i j}$, when $\mathrm{j} \in \mathrm{S}$ and $v_{j}^{-}=\max v_{i j}$, when $\mathrm{j} \in \mathrm{D}$ for $\mathrm{j}=1,2, \ldots, \mathrm{n}$ where $\mathrm{S}$-is a set of stimulants, D-is a set of destimulants.

Stage 6. Euclidean distances were calculated between every evaluated object (NUTS 4 unit) and the ideal positive solution $\mathrm{d}^{+}$and the ideal negative solution $\mathrm{d}^{-}$:

$$
d_{i}^{+}=\sqrt{\sum_{j=1}^{n}\left(v_{i j}-v_{j}^{+}\right)^{2}}, \quad d_{i}^{-}=\sqrt{\sum_{j=1}^{n}\left(v_{i j}-v_{j}^{-}\right)^{2}}, \quad i=1,2, \ldots, m
$$




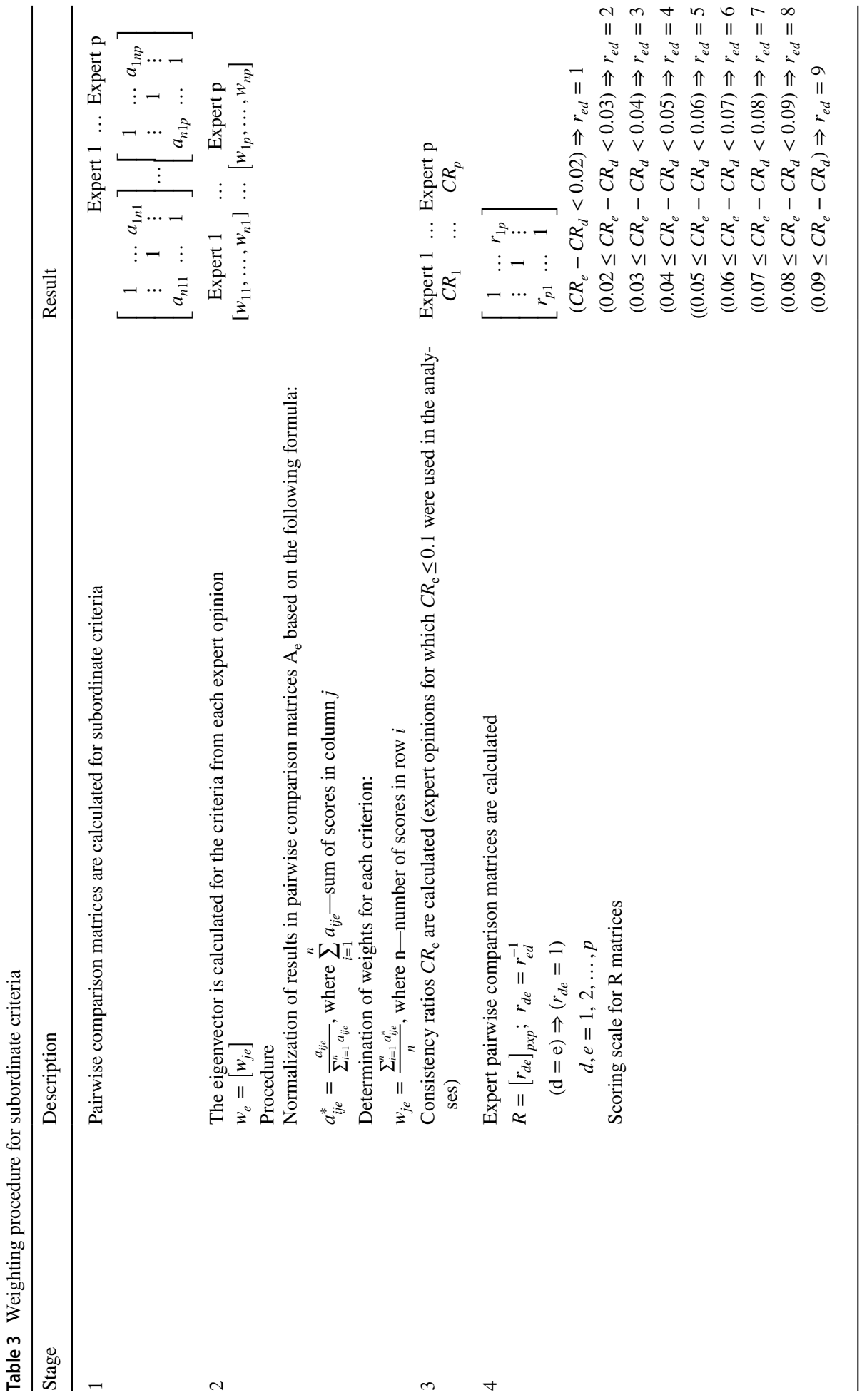




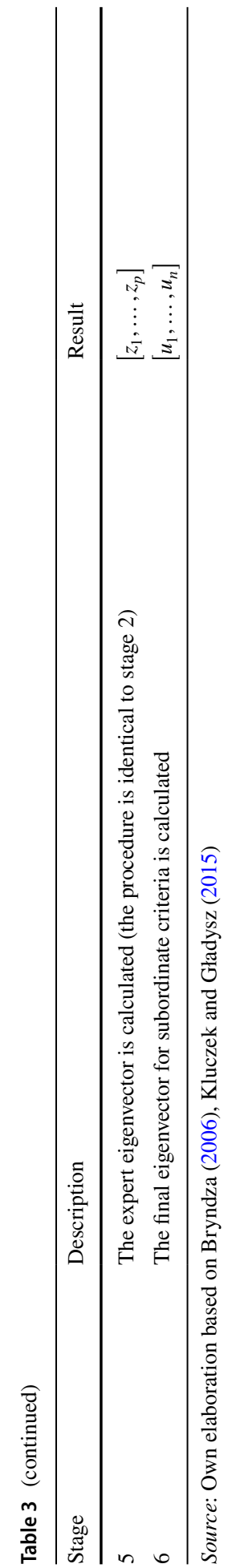

Springer 
Stage 7. A synthetic indicator was calculated for subordinate criteria and the main criterion:

$$
S_{i}=\frac{d_{i}^{-}}{d_{i}^{+}+d_{i}^{-}}, \quad \text { where } 0 \leq S_{i} \leq 1, \quad(\mathrm{i}=1,2, \ldots, \mathrm{m})
$$

Stage 8. The evaluated objects (NUTS 4 units) were arranged in a linear order and four typological classes were determined for the subordinate criteria (factors) and the main criterion (regional development) with the use of the arithmetic mean and standard deviation of the synthetic indicator (Wysocki 2010; Fura and Wang 2017):

- $S_{i} \geq \bar{S}_{i}+s_{S_{i}}$-class I-high values of: environmental, social and economic factors, overall regional development;

- $\bar{S}_{i} \leq S_{i}<\bar{S}_{i}+s_{S_{i}}$ class II-moderately-high values of: environmental, social and economic factors, overall regional development;

- $\bar{S}_{i}-s_{S_{i}} \leq S_{i}<\bar{S}_{i}$, -class III-moderately-low values of: environmental, social and economic factors, overall regional development;

- $S_{i}<\bar{S}_{i}-s_{S_{i}}$ - class IV-low values of: environmental, social and economic factors, overall regional development;

where

$S_{i}$ - value of the synthetic indicator calculated with the TOPSIS method for the subordinate criteria and the main criterion.

$\bar{S}_{i}$-arithmetic mean of synthetic indicator $S_{i}$,

$s_{S_{i}}$-standard deviation of synthetic indicator $S_{i}$.

The proposed classification was used to visualise spatial data relating to the analysed phenomena.

The development of the studied trans-border regions was analysed based on the data obtained from the Polish Central Statistical Office (GUS) and the Lithuanian Department of Statistics (Lietuvos Statistikos Departamentas).

\section{Results and Discussion}

In the first stage of the study, a hierarchical structure for evaluating regional development was developed based on the following subordinate criteria: environmental, social and economic factors. The applied indicators are presented in Table 4.

In stage 2, the AHP method was used to calculate weights for the subordinate criteria and simple parameters (indicators). The procedures described in Table 3 were used in this stage. The final values of parameter weights $\left(\mathrm{w}_{\mathrm{j}}^{*}\right)$ were calculated with the use of formula 8 (Table 5).

Parameter (indicator) values were normalised in stage 3 and weighted in stage 4 . In stage 5, the positive ideal solution was developed based on the desirable values of parameters (indicators) in all NUTS 4 units, and the negative ideal solution was developed based on the least desirable values of parameters (indicators) in all NUTS 4 units. 
Table 4 List of simple parameters (indicators) of regional development based on subordinate criteria

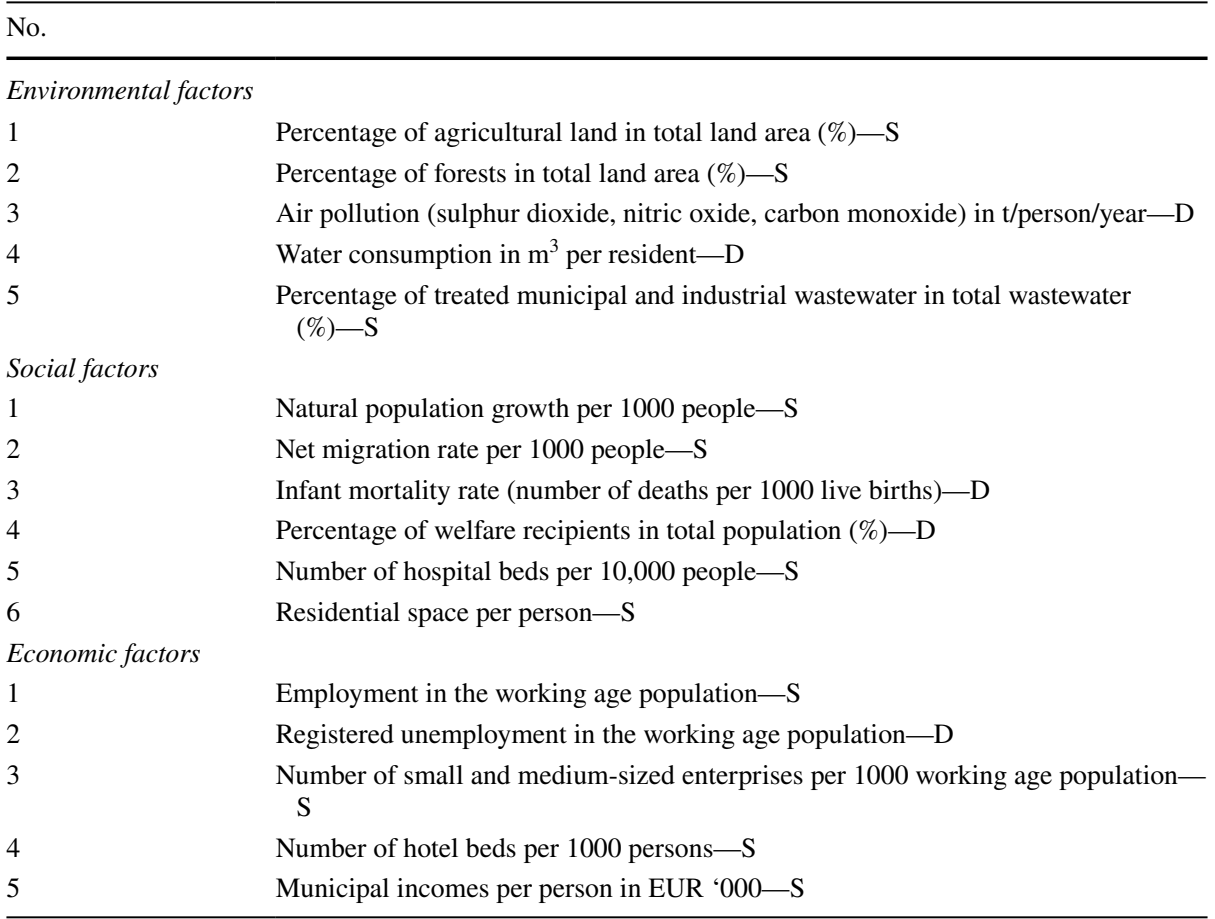

Source: Own elaboration based on Žičkienè (2004), Borys (2005), Vitunskiene et al. (2007), Heffner and Stanny (2007), Kompa (2009), Brodziński (2011), Bogdański (2012), Churski et al. (2014), Pociute (2014), Krupickaite et al. (2014), Streimikiene (2014), Ruplienė et al. (2017)

$S$ stimulant; $D$ destimulant

Table 5 Weights for subordinate criteria and parameters (indicators) describing the development of transborder regions

\begin{tabular}{|c|c|c|c|c|c|c|c|c|c|}
\hline \multirow[t]{2}{*}{ Specification } & \multicolumn{9}{|l|}{ Expert } \\
\hline & 1 & 2 & 3 & 4 & 5 & 6 & 7 & 8 & 9 \\
\hline Expert weight $\left(\mathrm{z}_{\mathrm{e}}\right)$ & 0.049 & 0.033 & 0.148 & 0.148 & 0.134 & 0.134 & 0.087 & 0.087 & 0.179 \\
\hline Subordinate criteria & \multicolumn{9}{|c|}{ Weights for subordinate criteria based on expert opinions $\left(\mathrm{w}_{\mathrm{je}}\right)$} \\
\hline Environmental factors & 0.083 & 0.600 & 0.072 & 0.072 & 0.102 & 0.081 & 0.091 & 0.600 & 0.120 \\
\hline Social factors & 0.193 & 0.200 & 0.232 & 0.232 & 0.211 & 0.168 & 0.455 & 0.200 & 0.272 \\
\hline \multirow[t]{2}{*}{ Economic factors } & 0.724 & 0.200 & 0.697 & 0.697 & 0.686 & 0.751 & 0.455 & 0.200 & 0.608 \\
\hline & & \multicolumn{3}{|c|}{$\begin{array}{l}\text { Weight indicators-subordi- } \\
\text { nate criteria }\left(\mathrm{u}_{\mathrm{j}}\right)\end{array}$} & \multicolumn{3}{|c|}{$\begin{array}{l}\text { Number of parameters pe } \\
\text { factor }\left(n_{p}\right)\end{array}$} & \multicolumn{2}{|c|}{$\begin{array}{l}\text { Parameter } \\
\text { weights } \\
\left(\mathrm{w}_{\mathrm{j}}^{*}\right)\end{array}$} \\
\hline Environmental factors & \multicolumn{3}{|c|}{0.152} & \multicolumn{4}{|c|}{5} & \multicolumn{2}{|c|}{0.030} \\
\hline Social factors & \multicolumn{3}{|c|}{0.241} & \multicolumn{4}{|c|}{6} & \multicolumn{2}{|c|}{0.040} \\
\hline Economic factors & \multicolumn{3}{|c|}{0.607} & \multicolumn{3}{|c|}{5} & & \multicolumn{2}{|c|}{0.121} \\
\hline
\end{tabular}

Source: Own elaboration 
In stage 6, Euclidean distances between the evaluated NUTS 4 units and positive and negative ideal solutions were calculated. In stage 4 , the results were used to determine the value of the synthetic indicator $\operatorname{Si}(i=1,2, \ldots, 48)$ for the subordinate criteria and the main criterion for NUTS 4 units. In stage 8, the analysed units were arranged in a linear order and 4 typological classes were identified.

The set of environmental factors for determining variations across NUTS 4 units involved indicators for describing the percentage of agricultural land and forests in total land area. The remaining three factors were largely indicative of the quality of the natural environment and its impact on living standards. Environmental quality is a key measure of the quality of life, and it exerts a direct influence on health because community members are increasingly likely to recognize the importance of local scenery and an unspoiled environment. Water, clean air, availability of space, forests and access to green areas satisfy basic human needs, create recreational options and contribute to the quality of life. The quality of the local environment also influences the local economy by enhancing the health of the local workforce and creating access to natural resources (Streimikiene 2014).

Poland and Lithuania are characterised by similar land-use types, and agriculture and forestry are the predominant types of land use (Senetra et al. 2013). In 2016, the percentage of agricultural land in total land area reached $60 \%$ and $53 \%$, and the percentage of forests $-30 \%$ and $34 \%$ in Poland and Lithuania, respectively (www.stat.gov.pl; www.stat. gov.lt). The area occupied by farmland is one of the key determinants of agricultural performance. In the analysed regions, the percentage of agricultural land in total land area was determined at $52.5 \%$ (Table 6), and it exceeded $65 \%$ in $30 \%$ of the investigated units in the county of Marijampole and the northern part of the Podlasie voivodship and the Warmia and Mazury voivodship. The analysed regions were also characterised by a high percentage of forests in total land area which reached $29.3 \%$ on average (Table 6). The above parameter exceeded $50 \%$ in $10 \%$ of the evaluated units. The Warmia and Mazury voivodship and the Podlasie voivodship are characterised by the most valuable natural habitats in Poland and Europe, and these areas are collectively referred to as the Green Lungs of Poland. These regions are renowned for their nature conservation areas, including the Białowieża National Park which is a UNESCO World Heritage Site, Biebrza National Park, Narew National Park, Wigry National Park, more than ten landscape parks and more than 270 nature reserves (Zielone Płuca 2009). The Lithuanian counties of Marijampole and Alytus feature extensive nature conservation sites such as the Čepkeliai-Dzūkija National Park

Table 6 Environmental factors in the evaluation regions in Poland and Lithuania

\begin{tabular}{llll}
\hline Environmental factors & \multicolumn{2}{l}{ Evaluated regions (average values) } \\
\cline { 2 - 4 } & Total & In Poland & In Lithuania \\
\hline Percentage of agricultural land in total land area (\%) & 52.5 & 56.2 & 38.8 \\
Percentage of forests in total land area (\%) & 29.3 & 27.7 & 35.5 \\
Air pollution (sulphur dioxide, nitric oxide, carbon monox- & 7.9 & 6.1 & 14.6 \\
$\quad$ ide) in t/person/year & & & 79.9 \\
Water consumption in m 3 /person/year & 79.0 & 78.8 & 60.4 \\
$\begin{array}{l}\text { Percentage of treated municipal and industrial wastewater } \\
\text { in total wastewater }(\%)\end{array}$ & 83.4 & 89.4 & \\
\hline
\end{tabular}

Source: Own elaboration

Total, average values for all NUTS 4 areas (in Poland and Lithuania) 
which is the largest national park in Lithuania, Zuvintas Biosphere Reserve, and Vištytis and Meteliai Regional Parks. The quality of the environment is significantly influenced by air, soil and water pollution. However, this study focused mostly on air pollution due to its scientifically proven influence on human health, as well as the scarcity of information about other types of pollution (Streimikiene 2014). Air pollution is measured in tonnes per person per year. Air pollution was determined based on the concentrations of sulphur dioxide, nitric oxide and carbon monoxide, and it was estimated at 22.0 in Poland and at 17.0 in Lithuania. In the evaluated regions, average air pollution was determined at 7.9 (Table 6), and it did not exceed 5.0 in $48 \%$ of the studied units. The protection and consumption of natural resources also play a crucial role in environmental assessments. Average water consumption, measured in $\mathrm{m}^{3}$ per person per year, was determined at 79 , which is a satisfactory result relative to the European average of around $420 \mathrm{~m}^{3} /$ person (cf. http://www.gios. gov.pl). The protection of water resources is of particular concern in the context of global climate change which is highly likely to deepen the existing water deficit around the world. At national level, water consumption was determined at $264 \mathrm{~m}^{3} /$ person in Poland and was significantly lower than in Lithuania where it reached $965 \mathrm{~m}^{3} /$ person. The total quantity of municipal and industrial wastewater and the percentage of treated sewage are also important considerations in environmental assessments. The percentage of treated sewage was similar in both analysed regions, and it was higher than that determined at the national level in both Poland and Lithuania (around 22\%). In the evaluated regions, $83.4 \%$ of municipal and industrial wastewater was treated (Table 6). The values of the above parameter varied considerably across the analysed units as well as in the entire evaluated region. The studied regions are also national leaders in terms of low air pollution, low water consumption and a high percentage of treated sewage in total wastewater.

The analysed units were divided into four classes based on the value of the synthetic indicator of environmental factors: from class I, representing the highest environmental standards to class IV, representing the lowest environmental standards (Fig. 3, Table 7). The highest indicator values were noted in territorial units with high environmental value and low levels of pollution.

Demographic potential was analysed based on natural population growth, net migration rate and infant mortality rate (number of deaths per 1000 live births). The potential of social infrastructure was assessed based on the percentage of welfare recipients in the total population, the number of hospital beds per 10,000 people and residential space per person.

Natural population growth and net migration rate are critical demographic metrics. Population density often determines a given area's attractiveness for potential dwellers (Pociute 2014). Natural population growth is the relationship between the number of births and deaths. In the evaluated area, average population growth per 1000 persons reached -2.4 (Table 8 ). Negative population growth was noted in around $70 \%$ of the analysed units. The highest number of territorial units with population growth below $-8.0 \%$ o were situated in Lithuania. Natural population growth varied across the evaluated regions in both Poland and Lithuania, and it was highest in urban areas. The net migration rate is also an important parameter that determines population changes, spatial distribution of population, and the distribution of various age groups in a population. Migration processes are inherently connected with regional development and, to a certain extent, they reflect the rate and direction of changes in regional economy (Kołodzieczyk 2002). In the studied area, the average net migration rate per 1000 persons was determined at -5.8 (Table 8), and positive values were observed in only $10 \%$ of the analysed units, all of them in Poland. In both Poland and Lithuania, the highest values of the above parameter were noted in suburban rural units 


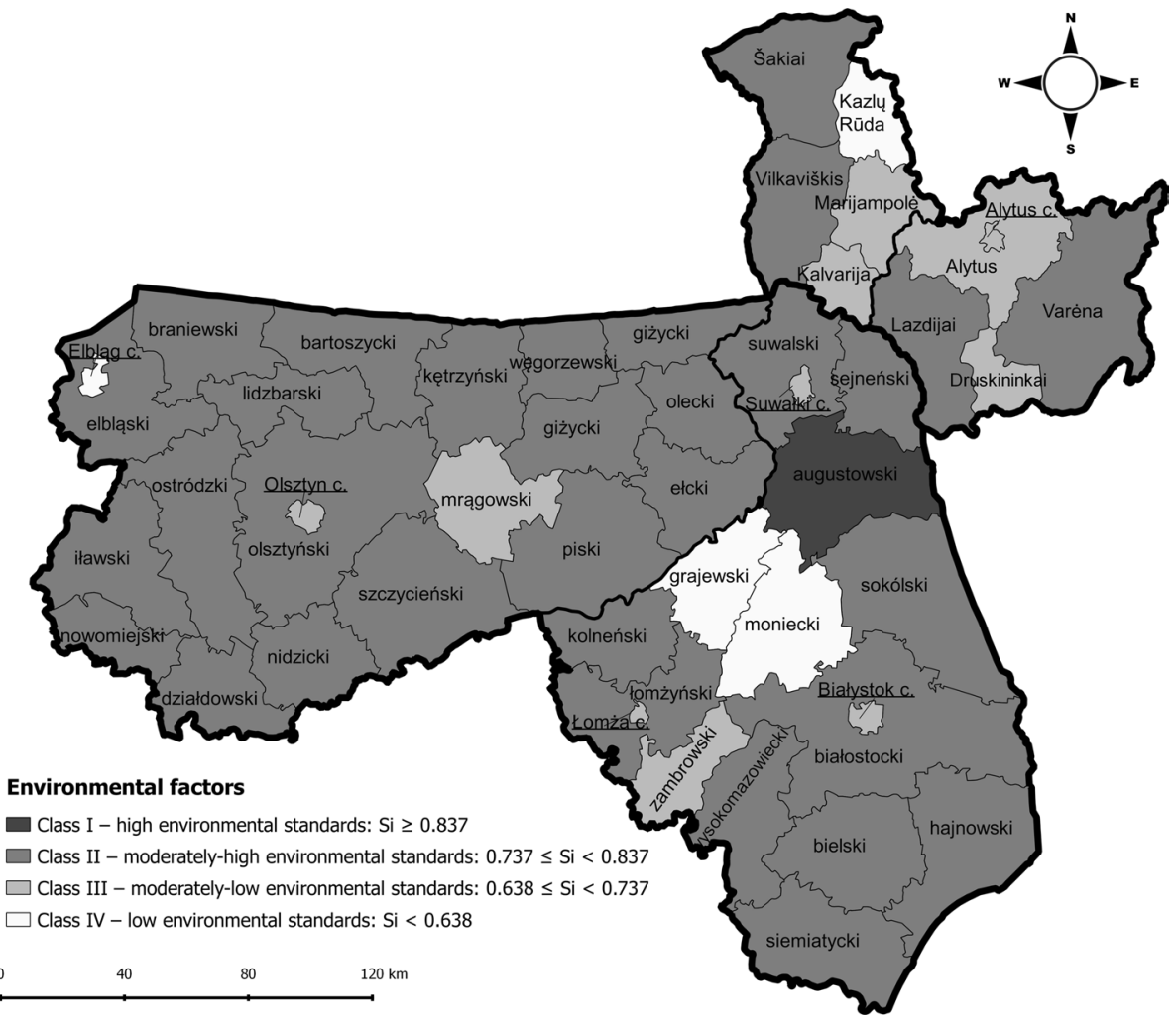

Fig. 3 Classification of NUTS 4 units based on environmental factors Source: Own elaboration

Table 7 Classification of NUTS 4 units based on environmental factors

\begin{tabular}{lccc}
\hline Class & $\begin{array}{l}\text { Total area } \\
\text { Percentage of evaluated units }\end{array}$ & \multicolumn{1}{c}{ In Poland } \\
\hline I & 2 & 2 & 0 \\
II & 67 & 74 & 40 \\
III & 23 & 16 & 50 \\
IV & 8 & 8 & 10 \\
Total & 100 & 100 & 100 \\
\hline
\end{tabular}

Source: Own elaboration

situated in the direct vicinity of regional capitals-Olsztyn, Białystok and Alytus. The net migration rate was below -5.0 in $41 \%$ of the evaluated territorial units in both countries. A high negative net migration rate can have adverse consequences for the distribution of various age groups in a population. The migration process involves mostly young people, and it depletes the local labour market. A low net migration rate combined with a low birth rate may also contribute to deepening the peripherality phenomenon (Pociute 2014). The infant mortality rate (number of deaths per 1000 live births) is also an important indicator 
Table 8 Social factors in the evaluated regions in Poland and Lithuania

\begin{tabular}{lrrr}
\hline Social factors & \multicolumn{3}{c}{ Evaluated regions (average values) } \\
\cline { 2 - 4 } & Total & In Poland & In Lithuania \\
\hline Natural population growth per 1000 people & -2.4 & -1.2 & -6.9 \\
Net migration rate per 1000 people & -5.8 & -2.8 & -17.2 \\
Infant mortality rate (number of deaths per 1000 live births) & 4.0 & 4.3 & 3.0 \\
Percentage of welfare recipients in total population (\%) & 9.6 & 10.7 & 5.3 \\
Number of hospital beds per 10,000 people & 38.7 & 40.9 & 30.6 \\
Residential space per person & 28.2 & 26.3 & 35.2 \\
\hline
\end{tabular}

Source: Own elaboration

Total, Average values for all NUTS 4 areas (in Poland and Lithuania)

of social standards and the quality of health care services. In the evaluated area, the average value of the above parameter reached 4.0, and it varied significantly between territorial units (Table 8). The infant mortality rate was lower in urban than in rural units. The condition and availability of social infrastructure and public services are as important determinants of living standards as income levels (Ciura 2010). In the evaluated area, there were 38.7 hospital beds per 10,000 persons (Table 3 ). This is not a satisfactory result relative to the Polish (48.6) and Lithuanian average (67.4). The value of this parameter varied considerably across the studied units and was higher in urban units. Living standards are also assessed based on the percentage of welfare recipients in a population. In the studied area, this parameter reached $9.6 \%$ on average and was relatively similar in the compared units. The following factor in the analysis was residential space per person, which was determined at $28 \mathrm{~m}^{2}$ on average in the evaluated area. The above factor was higher in territorial units with low levels of natural population growth and low net migration rate, which could have improved the availability of housing resources. The values of the above factors were higher in territorial units situated in the vicinity of large cities due to lower prices of real estate and the proximity of a large job market. It should be noted that the analysed regions were characterized by lower rates of natural population growth (Poland: $-0.15 \%$; Lithuania: $-3.6 \%$ ) and lower net migration rates (Poland: $0.04 \%$; Lithuania: $-10.5 \%$ ) relative to the respective national averages. The percentage of welfare recipients in total population was also below the national average in the evaluated regions (Poland: 6.5\%; Lithuania: $3.1 \%)$. A similar trend was noted in the number of hospital beds per 10,000 residents, in particular in the analysed Lithuanian region where the national average was nearly twice higher at 67.4. The corresponding difference was less pronounced in the evaluated Polish region (48.6 beds per 10,000 people). The differences in the number of infant deaths per 1000 live births (Poland: 4.0; Lithuania: 4.5) and residential space per person (Poland: 27.4; Lithuania: 33.6 ) were considerably smaller (refer to Table 8).

The analysed NUTS 4 units were divided into four classes based on the value of the synthetic indicator of social factors: from class I representing the highest social standards to class IV representing the lowest social standards. A comparison of classification results in both countries revealed a higher number of units with a better living standards in Poland than in Lithuania (Fig. 4, Table 9).

Class I units were characterised by high demographic potential with above average values of natural population growth per 1000 persons, net migration rate per 1000 


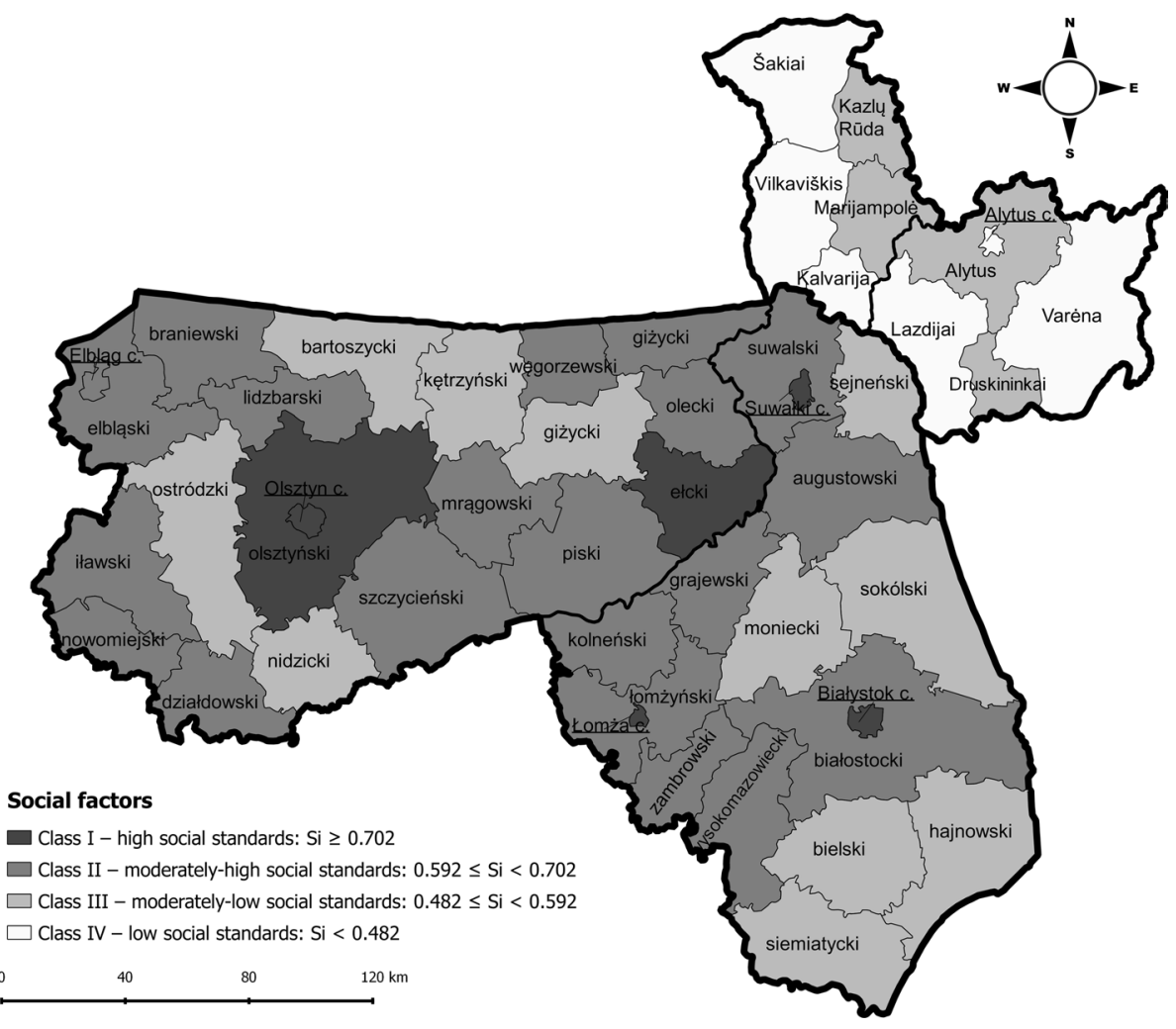

Fig. 4 Classification of NUTS 4 units based on social factors Source: Own elaboration

Table 9 Classification of NUTS 4 units based on social factors

\begin{tabular}{lccc}
\hline Class & $\begin{array}{l}\text { Total area } \\
\text { Percentage of evaluated units }\end{array}$ & $\begin{array}{c}\text { In Poland } \\
\text { In Lithuania }\end{array}$ \\
\hline I & 13 & 16 & 0 \\
II & 44 & 55 & 0 \\
III & 31 & 29 & 40 \\
IV & 12 & 0 & 60 \\
Total & 100 & 100 & 100 \\
\hline
\end{tabular}

Source: Own elaboration

persons and the number of hospital beds per 10,000 persons. The percentage of welfare recipients was below the average in class I units. Residential space per person was the only social parameter with below average value in the studied area. Territorial units in class IV were characterised by unfavourable values of natural population growth, net migration rate which were substantially below the average in the evaluated area. It should also be noted that class IV was composed only of Lithuanian NUT 4 units. 
Differences in the economic development of the evaluated areas were evaluated based on the following economic factors: employment in the working age population, registered unemployment in the working age population, number of small and medium-sized enterprises per 10,000 working age population, number of hotel beds per 1000 persons, municipal incomes per person in EUR ' 000 and total municipal spending per person in EUR '000. The first two factors characterise the labour market and unemployment. They describe human resources involved in social product development, and they are among the key determinants of economic growth that influence the overall socio-economic development of national economies (Knapińska 2008). The following three factors describe the financial status of the evaluated units, local business activity and entrepreneurship. Special attention should be paid to tourist services in the evaluated regions.

In the evaluated region, average employment in the working age population was determined at 47.5 (Table 10). This factor was characterised by strong spatial concentration, and the highest values were noted in Lithuania. Unemployment is a vital economic indicator which describes the labour market. In the evaluated region, average registered unemployment was $8.4 \%$, and it exceeded $10 \%$ in around $30 \%$ of the analysed units. In the evaluated region, average registered unemployment was $8.4 \%$, and it exceeded $10 \%$ in around $30 \%$ of the analysed units. Registered unemployment in the working age population is influenced by migration, which constitutes a serious problem on the labour market. After the EU enlargement of 2004, Polish and Lithuanian citizens gained access to EU labour markets, and some of the registered unemployed left their countries in search of foreign employment opportunities. Migration is strongly linked with socio-economic status which influences the flow of job seekers to or from a given region (Wilk et al. 2013). Small and medium-sized enterprises play an important role in economic growth. These businesses are flexible and capable of swiftly responding to changes in the business environment (Misztal 2015). The number of small and mediumsized enterprises was characterised by strong spatial concentration, and the highest values were noted in Poland. Tourism also contributes to economic growth (Chou 2013). The highest number of hotel beds per 1000 persons was determined in Druskininkai, a renowned Lithuanian spa town and balneology resort. Economic development is also determined by municipal incomes per capita which was determined at EUR 1000 per person in the evaluated area (Table 10). Municipal incomes per capita were similar in the evaluated area. An analysis of the evaluated regions revealed that municipal incomes

Table 10 Economic factors in the evaluated regions in Poland and Lithuania

\begin{tabular}{lrrr}
\hline Factor & \multicolumn{2}{l}{ Evaluated regions } \\
\cline { 2 - 4 } & Total & In Poland & In Lithuania \\
\hline Employment in the working age population & 47.5 & 41.4 & 70.7 \\
Registered unemployment in the working age population & 8.4 & 7.9 & 10.3 \\
Number of small and medium-sized enterprises per 1000 & 104.8 & 122.8 & 36.1 \\
$\quad$ working age population & & & 37.4 \\
Number of hotel beds per 1000 persons & 25.4 & 22.3 & 0.9 \\
Municipal incomes per person in EUR '000 & 1.0 & 1.0 & \\
\hline
\end{tabular}

Source: Own elaboration

Total, Average values for all NUTS 4 areas (in Poland and Lithuania) 
per person in EUR ' 000 (Poland: 1.1; Lithuania: 0.9) and employment in the working age population (Poland: 48.7; Lithuania: 77.3) approximated the respective national averages. In the studied regions, registered unemployment in the working age population exceeded national average values (Poland: 5.6; Lithuania: 7.9). The number of small and medium-sized enterprises per 1000 working age population was below the national average (Poland: 178.1; Lithuania: 58.8). In both evaluated regions, the number of hotel beds per 1000 persons was higher than the national average (Poland: 19.5; Lithuania: 27.1) (Table 10).

The analysed units were divided into four classes based on the value of the synthetic indicator of economic factors: from class I representing the highest values of economic factors to class IV representing the lowest values of economic factors (Fig. 5, Table 11). A comparison of Polish and Lithuanian areas revealed a higher number of better performing units in Poland.

An analysis of spatial variations in the synthetic indicator revealed that the values of economic factors were highest in units that are popular tourist destinations not only on the regional, but also on the national scale in both Poland and Lithuania. The lowest values of economic factors were noted in territorial units with the highest registered unemployment in the working age population. It should be noted that none of the analysed Polish and Lithuanian units met class IV criteria.

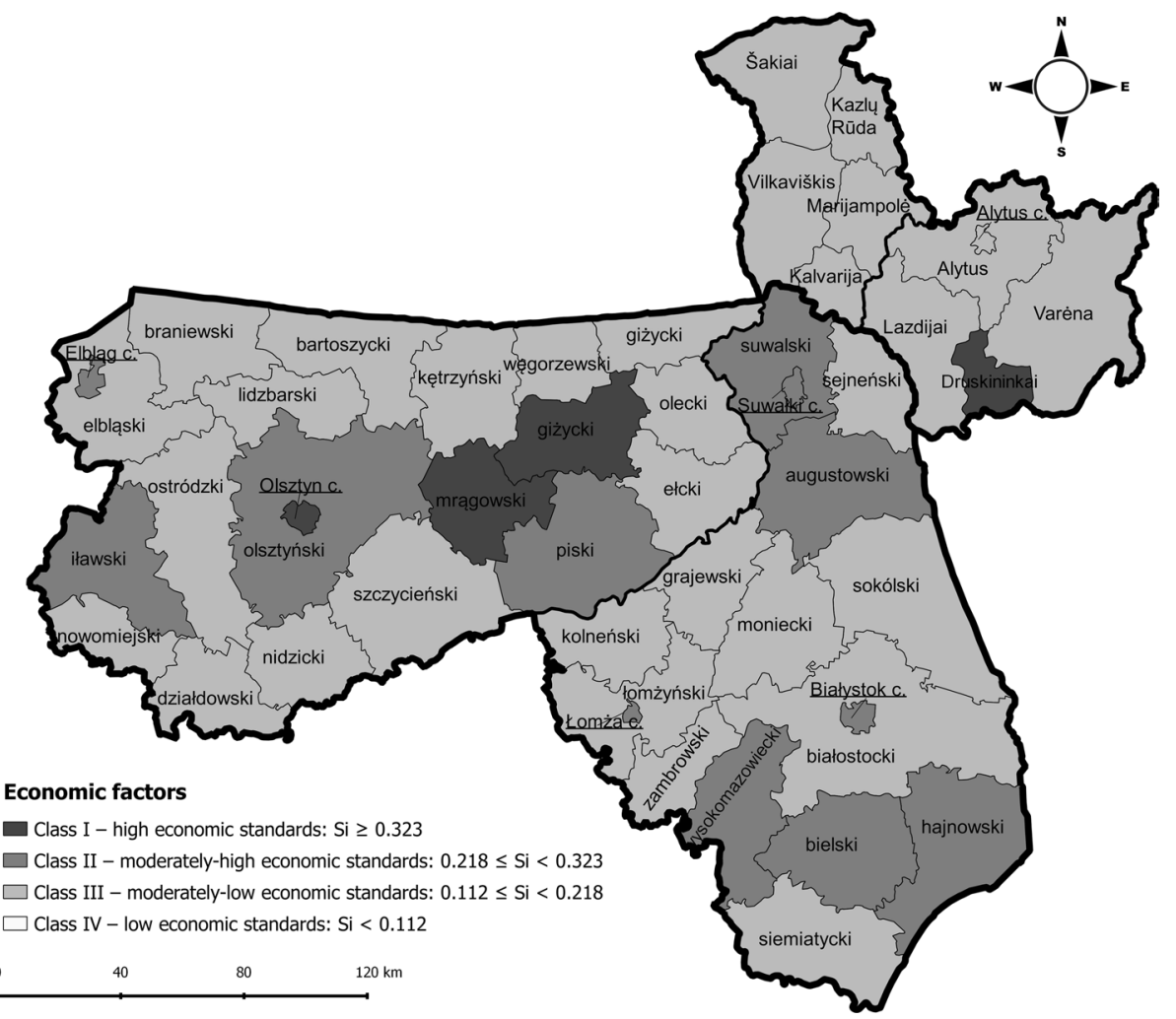

Fig. 5 Classification of NUTS 4 units based on economic factors Source: Own elaboration 
Table 11 Classification of NUTS 4 units based on economic factors

\begin{tabular}{lccc}
\hline Class & $\begin{array}{l}\text { Total area } \\
\text { Percentage of evaluated units }\end{array}$ & \multicolumn{1}{c}{ In Poland } \\
& 8 & 8 & 10 \\
I & 25 & 32 & 0 \\
II & 67 & 60 & 90 \\
III & 0 & 0 & 0 \\
IV & 100 & 100 & 100 \\
Total & & & \\
\hline
\end{tabular}

Source: Own elaboration

Based on the constituent elements of environmental, social and economic factors, the distribution of the synthetic indicator for the main criterion formed spatial foci of social and economic activity. The majority of territorial units with the highest levels of development significantly contributed to the development of tourism. These areas were characterised by high economic potential and relatively low environmental and social potential. High social potential was observed only in the city of Olsztyn. A comparison of territorial units allocated to different classes based on the main criterion revealed a higher number of higher-scoring areas in Poland (Fig. 6, Table 12). The noted results could be attributed

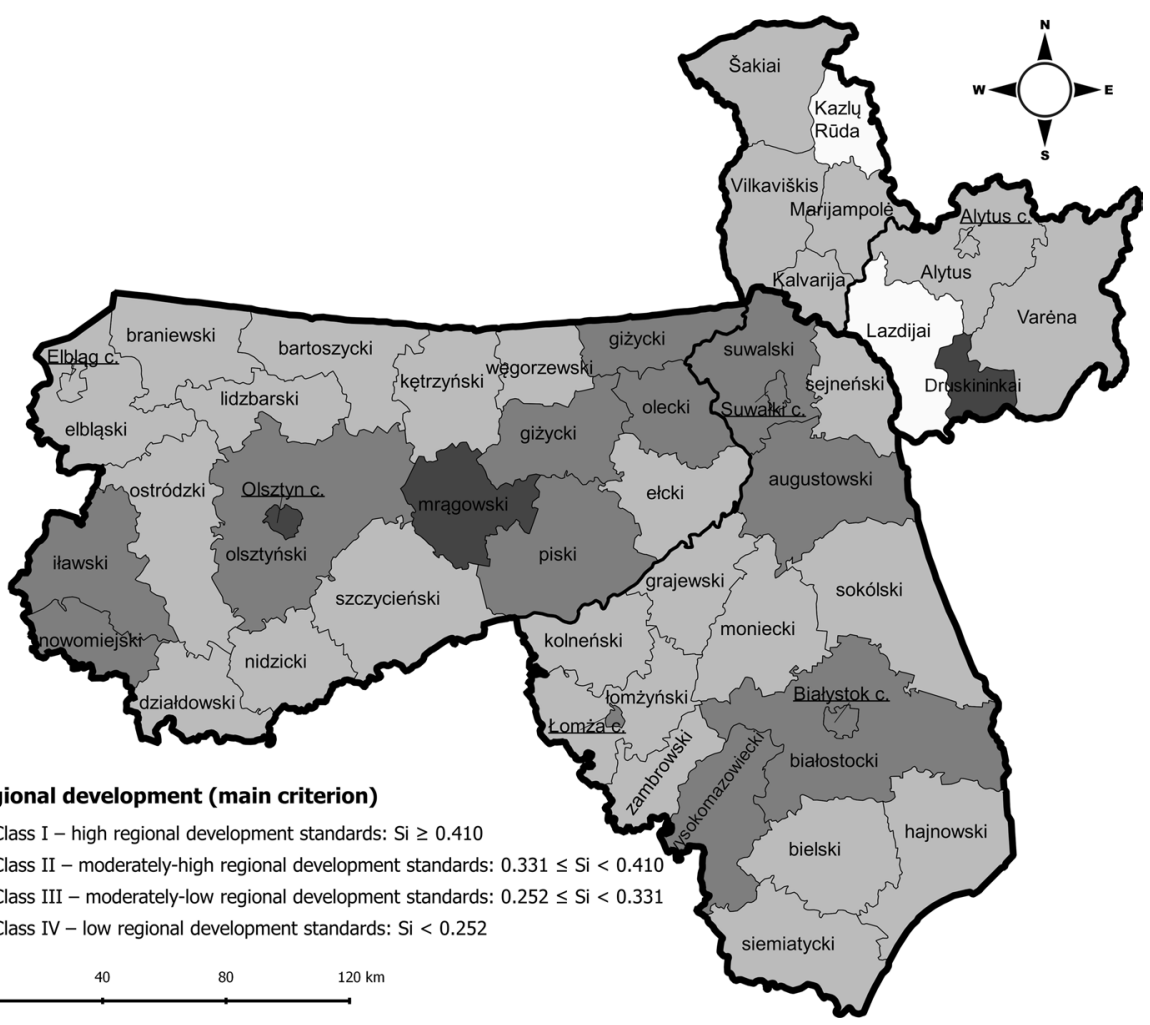

Fig. 6 Classification of NUTS 4 units based on the main criterion Source: Own elaboration 
Table 12 Classification of NUTS 4 units based on the main criterion (overall development of trans-border regions)

\begin{tabular}{lccc}
\hline Class & $\begin{array}{l}\text { Total area } \\
\text { Percentage of evaluated units }\end{array}$ & $\begin{array}{c}\text { In Poland } \\
\text { In Lithuania }\end{array}$ \\
\hline I & 6 & 5 & 10 \\
II & 29 & 37 & 0 \\
III & 61 & 58 & 70 \\
IV & 4 & 0 & 20 \\
Total & 100 & 100 & 100 \\
\hline
\end{tabular}

Source: Own elaboration

to a combination of two factors. Firstly, the peripheral location of the studied areas has a detrimental impact on their socioeconomic development, which is manifested by below average values of social and economic indicators, both in Poland and Lithuania. Secondly, Lithuania is characterised by a lower rate of economic growth than Poland, as well as unfavourable demographic trends due to low population growth and a high negative net migration rate. The analysed Polish and Lithuanian regions are undoubtedly areas of great scenic beauty with considerable potential for tourism development. The results of this study confirm that local resources significantly contribute to socioeconomic growth, which is why environmental, social and economic factors should be taken into account when planning regional development.

\section{Conclusions}

The following conclusions can be formulated based on the analysis of the development of NUTS 4 units in Poland (Warmia and Mazury voivodship, Podlasie voivodship) and Lithuania (counties of Marijampolè and Alytus):

1. Environmental, social and economic factors are characterised by considerable spatial variations in the evaluated area.

2. The analysed area is characterised by high natural value. The values of environmental factors were high and moderately-high (class I and class II) in nearly $70 \%$ of the evaluated territorial units. This is a very important observation because the quality of the natural environment is a key indicator of living standards, and it directly influences the quality of life.

3. The analysed area was characterised by considerable demographic problems resulting from low natural population growth and high negative net migration rate. These factors directly influence the distribution of various age groups in a population and labour market resources. Demographic problems were more pronounced in Lithuania than in Poland.

4. The highest values of economic factors were noted in units with well-developed tourism infrastructure. In the evaluated area, nearly $65 \%$ of territorial units were characterised by moderately-low and low values of economic factors.

5. The distribution of the synthetic indicator for the main criterion was influenced by social and economic activity. Economic factors had the greatest impact on the final results. 
Open Access This article is distributed under the terms of the Creative Commons Attribution 4.0 International License (http://creativecommons.org/licenses/by/4.0/), which permits unrestricted use, distribution, and reproduction in any medium, provided you give appropriate credit to the original author(s) and the source, provide a link to the Creative Commons license, and indicate if changes were made.

\section{References}

Angelovič, M., \& Ištok, R. (2016). How to assess quality of life. Theoretical and methodological research aspects in trans-border regions. In D. Szymańska \& J. Chodkowska-Miszczuk (Eds.), Bulletin of geography. Socio-economic series (Vol. 32, pp. 19-32). doi: http://dx.doi.org/10.1515/bog-2016-0012.

Babic, Z., \& Plazibat, N. (1998). Ranking of enterprises based on multi-criteria analysis. International Journal of Production Economics, 56-57, 29-35.

Bogdański, M. (2012). Socio-economic potential of Polish cities-A regional dimension. In D. Szymańska and J. Biegańska (Eds.), Bulletin of geography. Socio-economic Series (Vol. 17, pp. 13-20). http:// dx.doi.org/10.2478/v10089-012-0002-8.

Borys, T. (Ed.). (2005). Wskaźniki zrównoważonego rozwoju. Warszawa-Białystok: Ekonomia i Środowisko.

Brodziński, Z. (2011). Stymulowanie rozwoju obszarów wiejskich na poziomie lokalnym na przykładzie gmin województwa warmińsko-mazurskiego. Warszawa: Wydawnictwo Szkoły Głównej Gospodarstwa Wiejskiego.

Bryndza, J. (2006). Analiza hierarchiczna problemu w szacowaniu ryzyka projektu informatycznego metodą punktową. Systemy Wspomagania Organizacji (pp. 395-403). Katowice: Akademia Ekonomiczna.

Central Statistical Office (GUS). http://www.stat.gov.pl. Accessed 20 March 2018.

Chou, M. C. (2013). Does tourism development promote economic growth in transition countries? A panel data analysis. Economic Modelling, 33, 226-232.

Churski, P., Burneika, D., \& Korec, P. (2014). Areas of economic growth and areas of stagnation as objects of special intervention in the regional policies of European Union member states: An international comparison. In P. Churski (Ed.), The social and economic growth versus the emergence of economic growth and stagnation areas (pp. 151-188). Poznań: Bogucki Wydawnictwo Naukowe.

Ciura, G. (2010). Warunki życia ludności wiejskiej. Studia BAS, 4(24), 159-178.

Cross Border Cooperation Programme Lithuania-Poland. (2007). European Regional Development Fund 2007-2013 Objective 3: European Territorial Cooperation.

Ding, L., Shao, Z., Zhang, H., Xu, C., \& Wu, D. (2016). A comprehensive evaluation of urban sustainable development in china based on the TOPSIS-entropy method. Sustainability, 8, 746. https://doi. org/10.3390/su8080746.

Fura, B., \& Wang, Q. (2017). The level of socioeconomic development of EU countries and the state of ISO 14001 certification. Quality \& Quantity, 51(1), 103-119.

Gwiaździńska-Goraj, M., \& Jezierska-Thole, A. (2013). Peryferyjność obszarów wiejskich województwa warmińsko-mazurskiego a zmiany ludnościowe w latach 1988-2011. Studia Obszarów Wiejskich, XXXIV, 176-185.

Hanine, M., Boutkhoum, O., Tikniouine, A., \& Agouti, T. (2016). Application of an integrated multi-criteria decision making AHP-TOPSIS methodology for ETL software selection. SpringerPlus, 5, 263. https://doi.org/10.1186/s40064-016-1888-z.

Heffner, K., \& Stanny, M. (2007). Zróżnicowanie gmin wiejskich ze względu na poziom rozwoju społecznogospodarczego. In A. Rosner (Ed.), Zróżnicowanie poziomu rozwoju społeczno-gospodarczego obszarów wiejskich a zróżnicowanie dynamiki przemian (pp. 153-164). Warszawa: Instytut Rozwoju Wsi i Rolnictwa Polskiej Akademii Nauk w Warszawie.

Holgado Molina, M. M., Salinas Fernández, J. A., \& Rodríguez Martín, J. A. (2015). A synthetic indicator to measure the economic and social cohesion of the regions of Spain and Portugal. Revista de Economía Mundial, 39, 223-240.

Huang, I. B., Keisler, J., \& Linkov, I. (2011). Multi-criteria decision analysis in environmental sciences: Ten years of applications and trends. Science of the Total Environment, 409(19), 3578-3594. https://doi. org/10.1016/j.scitotenv.2011.06.022.

Hwang, C. L., \& Yoon, K. (1981). Multiple attribute decision making: Methods and applications: A state of the art survey. Berlin: Springer.

Kluczek, A., \& Gładysz, B. (2015). Analytical hierarchy process/technique for order preference by similarity to ideal solution-based approach to the generation of environmental improvement options for painting process. Results from an industrial case study. Journal of Cleaner Production, 101, 360-367. https ://doi.org/10.1016/j.jclepro.2015.03.079. 
Knapińska, M. (2008). Transformacja zasobów pracy w Polsce w latach 1990-2006. Polityka Społeczna, 2, 6-10.

Kołodziejczyk, D. (2002). Ocena potencjału demograficznego gmin w Polsce (w aspekcie ilościowym i jakościowym). Studia Obszarów Wiejskich, 2, 19-30.

Kompa, K. (2009). Budowa mierników agregatowych do oceny poziomu rozwoju społeczno-gospodarczego. Zeszyty Naukowe SGGW: Ekonomika i Organizacja Gospodarki Żywnościowej, 74, 5-26.

Kowalik, J., Zawada, M., \& Kucęba, R. (2017). Regional diversification of the level of economic development in Poland. International Journal of Social Sciences, 3(2), 730-745. https://doi. org/10.20319/pijss.2017.32.730745.

Krupickaite, D., Konecka-Szydłowska, B., \& Hauke, J. (2014). Spatial variability in the socio-economic development in terms of population and settlement at the level of NUTS 4 units. The case study of Poland, Slovakia and Lithuania. Rozwój Regionalny i Polityka Regionalna, 25, 135-149.

Kusumawardani, R. P., \& Agintiara, M. (2015). Application of Fuzzy AHP-TOPSIS method for decision making in human resource manager selection process. Procedia Computer Science, 72, 638-646. https://doi.org/10.1016/j.procs.2015.12.173.

Łuczak, A., \& Wysocki, F. (2012). Zastosowanie uogólnionej miary odległości GDM oraz metody TOPSIS do oceny poziomu rozwoju społeczno-gospodarczego powiatów województwa wielkopolskiego. Przeglad Statystyczny, numer specjalny, 2, 298-311.

Mačiulytė, J., Veteikis, D., \& Šabanovas, S. (2012). Recomposition of rural space in Lithuania since the restoration of independence. Acta Scientiarium Polonorum. Administratio Locorum, 1(3), 167-183.

Markowski, T. (2008). Teoretyczne podstawy rozwoju lokalnego i regionalnego. In Z. Strzelecki (Ed.), Gospodarka regionalna i lokalna (pp. 13-28). Warszawa: Wydawnictwo Naukowe PWN.

Martin, R. (2001). Geography and public policy: The case of the missing agenda. Progress in Human Geography, 25(2), 189-210. https://doi.org/10.1191/030913201678580476.

Milenkovic, N., Vukmirovic, J., Bulajic, M., \& Radojicic, Z. (2014). A multivariate approach in measuring socio-economic development of MENA countries. Economic Modelling, 38, 604-608. https:// doi.org/10.1016/j.econmod.2014.02.011.

Misztal, A. (2015). Sytuacja gospodarcza Polski a rozwój małych i średnich przedsiębiorstw. Gospodarka w Praktyce i Teorii, 3(40), 65-78. https://doi.org/10.18778/1429-3730.40.04.

Mitriča, B., Mocanu, I., Dumitraşcu, M., \& Grigorescu, I. (2017). Socio-economic disparities in the development of the Romania's border areas. Social Indicators Research, 134(3), 899-916. https:// doi.org/10.1007/s11205-016-1462-7.

Mukherjee, K. (2017). Supplier selection. An MCDA-based approach. Studies in systems. Decision and control 88. Springer, New Delhi. https://doi.org/10.1007/978-81-322-3700-6.

Newman, D., \& Paasi, A. (1998). Fences and neighbours in the postmodern world: Boundary narratives in political geography. Progress in Human Geography, 22(2), 186-207. https://doi. org/10.1191/030913298666039113.

Nowa encyklopedia powszechna PWN. (1996). Warszawa: Wydawnictwo Naukowe PWN.

Pacione, M. (2003). Urban environmental quality and human wellbeing-A social geographical perspective. Landscape and Urban Planning, 65(1-2), 21-32. https://doi.org/10.1016/S0169 -2046(02)00234-7.

Pawlewicz, A., Cieślak, I., Pawlewicz, K., \& Szuniewicz, K. (2015). Natura 2000 sites and socio-economic development of rural communes in eastern Poland. In 16th International scientific conference proceedings, economic science for rural development 2015, integrated and sustainable regional development (Vol. 38, pp. 14-23). Jelgava: Latvia University of Agriculture.

Pérez, A. G., López, M. H., \& Echeverría, F. R. (2015). Sustainable Development synthetic indicators based on distance for Venezuela. In 7th International conference on urban rehabilitation and sustainability, mechanics. Energy, environment (Vol. 42, pp. 194-200). Rome: WSEAS Press.

Pociute, G. (2014). Trends of imbalances of demographic and socioeconomic development in the postreform period in Lithuania. In P. Churski (Ed.), The social and economic growth versus the emergence of economic growth and stagnation areas (pp. 129-150). Poznań: Bogucki Wydawnictwo Naukowe.

Raupeliene, A., Stabingis, L., \& Jazepcikas, D. (2014). Employment development in rural regions: Strategic orientations for better targeted policy. Akademija: Aleksandras Stulginskis University.

Ruplienè, D., Garšvienė, L. Rudytė, D., Skunčikienė, S., \& Bajorūnienė, R. (2017). The evaluation of impact of municipalities fiscal competitiveness on economic growth. In $C B U$ international conference on innovations in science and education. http://dx.doi.org/10.12955/cbup.v5.958.

Saaty, T. L. (2000). Fundamentals of decision making and priority theory with the analytic hierarchy process. Analytic hierarchy process series (Vol. 6). 
Sarul, L.S., \& Eren, Ö. (2016). The comparison of MCDM methods including AHP, TOPSIS and MAUT with an application on gender inequality index. European Journal of Interdisciplinary Studies, 4(2), 181-194. http://journals.euser.org/files/articles/ejis_jan_apr_16/Latife.pdf. Accessed 10 May 2018.

Senetra, A., Szczepańska, A., Veteikis, D., Wasilewicz-Pszczółkowska, M., Šimanauskienė, R., \& Volungevičius, J. (2013). Changes of the land use patterns in Polish and Lithuanian trans-border rural area. Baltica, 26(2), 157-168. https://doi.org/10.5200/baltica.2013.26.16.

Song, T., Cheng, Y., Liu, W. D., \& Liu, H. (2017). Spatial difference and mechanism of influence of geoeconomy in the border areas of China. Journal of Geographical Sciences, 27(12), 1463-1480. https ://doi.org/10.1007/s11442-017-1447-8.

Statistics Lithuania. http://www.stat.gov.lt/. Accessed 20 March 2018.

Stoltmann, A. (2015). Zastosowanie metody AHP do porównania kryteriów wyboru lokalizacji budowy farmy wiatrowej. Zeszyty Naukowe Wydziału Elektrotechniki i Automatyki Politechniki Gdańskiej, 42, 187-190.

Streimikiene, D. (2014). Comparative assessment of environmental indicators of quality of life in Romania and Lithuania. Economics \& Sociology, 7(1), 11-21. https://doi.org/10.14254/2071-789X.2014/7-1/2.

Tzneng, G. H., \& Huang, J. J. (2011). Multiple attribute decision making methods and applications. New York: Taylor \& Francis Group.

Veenhoven, R. (2002). Why social policy needs subjective indicators. Social Indicators Research, 58(1-3), 33-45. https://doi.org/10.1023/A:1015723614574.

Vitunskiene, V., Jazepcikas, D., \& Janusauskaite, G. (2007). The unevenness of life quality in Lithuania's rural areas: Economic and social dimensions. In The role of social capital and grass-roots in initiatives in rural development. Proceedings of international symposium. management theory and studies for rural business and infrastructure development (Vol. 1(8), pp. 263-270).

Wilk, J., Pietrzak, M. B., \& Matusik, S. (2013). Sytuacja społeczno-gospodarcza jako determinanta migracji wewnętrznych w Polsce. Prace Naukowe Uniwersytetu Ekonomicznego we Wrocławiu Taksonomia, 20(278), 330-342.

Wyniki narodowego spisu powszechnego ludności i mieszkań 2011. (2012). Warszawa: Główny Urząd Statystyczny.

Wysocki, F. (2010). Metody taksonomiczne w rozpoznawaniu typów ekonomicznych rolnictwa i obszarów wiejskich. Poznań: Uniwersytet Przyrodniczy.

Žičkienė, S. (2004). Lietuvos darnus vystymasis: eksperimentinis vertinimas. Environmental Research, Engineering and Management, 1(27), 15-20.

Zielone Płuca Polski-walory przyrodnicze i kulturowe. (2009). In K. Wolfram (Ed.), Białystok: Fundacja Zielone Płuca Polski.

Publisher's Note Springer Nature remains neutral with regard to jurisdictional claims in published maps and institutional affiliations.

\section{Affiliations}

\section{Katarzyna Pawlewicz ${ }^{1}$ (D) Adam Senetra ${ }^{1}$ (D) Marta Gwiaździńska-Goraj ${ }^{1}$ (D) . Dovilè Krupickaité ${ }^{2}$}

Katarzyna Pawlewicz

katarzyna.pawlewicz@uwm.edu.pl

Marta Gwiaździńska-Goraj

marta.gwiazdzinska-goraj@uwm.edu.pl

Dovilè Krupickaitè

dovile.krupickaite@gf.vu.1t

1 Institute of Geography and Land Management, Faculty of Geodesy, Geospatial and Civil Engineering, University of Warmia and Mazury in Olsztyn, Prawocheńskiego Str. 15, 10-720 Olsztyn, Poland

2 Department of Geography and Land Management, Institute for Geosciences, Vilnius University, M. K. Čiurlionio 21, 03101 Vilnius, Lithuania 